\title{
Introduction to 'Theoretical Pathways': Thinking About Human Endeavour During the Middle Stone Age and Middle Palaeolithic
}

\author{
Anders Högberg ${ }^{1,2,3}$ (1) $\cdot$ Marlize Lombard ${ }^{2,3}$ (C)
}

Accepted: 15 December 2020 / Published online: 12 January 2021

(C) The Author(s) 2021

\begin{abstract}
In this brief introduction, we present and contextualise 'theoretical pathways' elaborated in this special issue, in terms of understanding humanity from a deep-time perspective. The participating authors discuss a wide range of approaches related to thinking about human endeavour during the Middle Stone Age and Middle Palaeolithic ranging from the constraints of technological niches and Material Engagement Theory to aspects of palaeo-neurology, agent-based models of self-domestication and coevolutionary model building. Together, the contributions demonstrate that current theoretical approaches that aim to explain deep-time human endeavour require multidisciplinary approaches, and that for some researchers, the trend is to move away from the symbolic standard or models of sudden mutation. By doing so, each contribution, in its own way, enhances our understanding of 'being' or 'becoming' human during the time slice between 300,000 and 30,000 years ago. The work represented here makes it increasingly clear that a singular or particular aspect did not 'give birth' to Homo sapiens in Africa during the Middle Stone Age and/or in Eurasia during the Middle Palaeolithic. Instead, humanity in all its complexity was probably shaped by a broad range of factors and processes that took place over an extended period.
\end{abstract}

Keywords Human origins · Thought style · Thought collective · Palaeo-neurology · Symbolic behaviour $\cdot$ Co-evolution $\cdot$ Self-domestication

Anders Högberg

anders.hogberg@lnu.se

1 School of Cultural Studies, Archaeology, Linnaeus University, SE-391 82 Kalmar, Sweden

2 Palaeo-Research Institute, University of Johannesburg, P.O. Box 524, Auckland Park ZA-2006, South Africa

3 Stellenbosch Institute for Advanced Study (STIAS), Wallenberg Research Centre at Stellenbosch University, Stellenbosch 7600, South Africa 


\section{Introduction}

In recent decades, few archaeological periods have produced as much new data and discoveries across a range of disciplines as the period dating to roughly between 300,000 and 30,000 years ago, which is the focus of this special issue. Landmark finds and cutting-edge techniques have resulted in new ways to understand humanity from a long-term perspective. Archaeological interpretation, however, is grounded in the mind of the researcher. Even though we sometimes hear that 'the evidence speaks for itself', this is simply not correct. Evidence does not speak. It is built into and explained through processes, and as such it is influenced by knowledge and know-how situated in specific contexts (Baghramian and Carter 2020). Fleck (1935) introduced the concepts of 'thought style' and 'thought collective' to unfold how this plays out (also see Wenger's 1998 discussion on 'Communities of Practice'). As discussed by Holtorf and Högberg (2015: 511), 'a 'thought collective' is the result of a group of people reciprocally exchanging ideas or maintaining intellectual interaction and, in doing so, becoming more and more skilled and specialized'. What is implicitly understood as common knowledge within the group is reproduced, and a special way of doing research develops. Certain ways of perceiving and thinking are adopted-for example, ways of determining what kind of questions are relevant to ask, which kind of methods to apply, how to conduct the analysis, and in which style and context to present results. Hence, a specific thought style is established. Every thought style within a thought collective develops certain ways of thinking that encourage the feeling of 'shared minds', connecting the group members and inspiring people to think and act in certain ways, and not others (Fleck 1935).

This has been realised within archaeology for decades, and at least since the 1950s resulted in a substantial amount of theoretical thinking, writing, and doing. Here we do not want to repeat this history (see Trigger 2006), but it is easy to observe that we can see theoretical thinking that guard, defend, and protect, as well as analytical studies that expand on and break with current established thought styles (also see Hodder 2005; Johnson 2020 for discussion).

When Daniel Miller (2005: 212) writes that the "contemporary archaeologist is by and large considered profound or at least good at their work largely to the extent to which they are able to transcend the merely manifest in the objects which they uncover and see through these fragments to the reality of the social and cultural lives of which they are mere remnants," he stereotypes a well-established theoretical position about what archaeologists do (e.g. Binford 1962; Hodder 1986; Renfrew and Zubrow 1994; Meskell and Preucel 2004). It draws on what Herzfeld (2001) discussed as a 'common sense based' generally accepted thought style that archaeology is about understanding prehistoric people, getting close to them, and entering the minds of those long dead to reveal their intentions, meanings, and purposes. An example is when Hodder (1986: 82) writes: "It is only when we make assumptions about the subjective meanings in the minds of people long dead that we can begin to do archaeology". Here, to explore what happened in the past, to understand people in prehistory on their own terms, and to use methods that capture their perception of the world is what archaeologists do (e.g. Lucas 2005; Olsen 2010). This is, however, just one of many ways to appreciate the theoretical endeavours of archaeologists (see Högberg 2009). 
Alternatives emphasise archaeology as, for example, a contemporary practice and a set of experiences (Shanks 1992), and as such a well-appreciated way in our own time to explore narratives about the past to make sense in the present (e.g. Holtorf 2005). Still others would argue that archaeology is not only about understanding people of the past and their perception of the world, but about understanding humanity from a deeptime perspective (Donald 1991, 2001; Smail 2008), and by doing so to explore what prehistoric people did not know about themselves, but what we can learn today about humanity from a long-term perspective. We suggest that this theoretical approach is especially pertinent in archaeological research that is framed by an evolutionary perspective.

\section{The Volume Contextualised}

The first two decades of this millennium saw ground-breaking discoveries in material (e.g. archaeological, fossil, and genetic data) and method (e.g. advances in analytical, statistical, biomolecular, and digital approaches) pertaining to the time slice of roughly 300,000 to 30,000 years ago. Some of these breakthroughs changed forever how we think about the origins of our species, the early knowledge systems of our Homo sapiens ancestors, and their interaction with other humans on the landscapes of the Old World. The Middle Stone Age in Africa and Middle Palaeolithic in Eurasia are different in their deep histories (see Kuhn and Hovers 2013 for discussion). In Africa, we see the evolution of $H$. sapiens in interaction with other Homo species over hundreds of thousands of years. In Eurasia Neanderthals, and in the east also Denisovans, roamed the ancient landscapes. With $H$. sapiens venturing out of Africa sometime between 100,000 and 70,000 years ago, we see the early spread of this 'new' population over vast regions in Eurasia. As their foraging range expanded, they interacted with other human groups they happened upon. Whilst we do not yet know the nature and implications of these encounters, we do know that genes were exchanged and that ultimately, sometime during the last tens of thousands of years of the time slice that represent the focus of this special issue, $H$. sapiens became the sole human survivor in both Africa and Eurasia. Whereas striking new individual finds, and impressive methodological advances and results, help to provide glimpses into human biological adaptations and cogni-behavioural repertoires during the Middle Stone Age and Middle Palaeolithic, theoretical understanding of the processes behind the flurry of empirical reporting has emerged as a field of study in itself.

Theory in archaeology comes in many forms, as theory-driven exploration to consider ranges of possibilities in archaeological interpretation or in studies testing a particular theory against a given set of data. Beck et al. (2019: 17) noticed that there are researchers that employ theory without making a fuss about it, and "there is the main bulk of archaeological texts in which theory is implicit in the sense that all archaeology is based on some general theory of how the world works". Research on human endeavour during the 300,000-to-30,000-year time slice is no exception. Glossing over a selection of the vast amount of studies presented from the last decades, we find analyses set in various thought styles, from those that do not actively engage in any theoretical thinking, to those presenting elaborate hypotheses based on deep theoretical discussion as an integrated part of the results. 
Theory at its best enables us to scrutinise established thought styles and provides us with new ways of thinking that facilitate the formulation of new kinds of research questions. With this volume, we bring together a collection of papers that offers rich and novel ways of asking questions and thinking about human endeavour during the Middle Stone Age and Middle Palaeolithic. All the participating authors grapple critically with increasing our depth of understanding different aspects of human evolution and enterprise during this critical phase in our coming of age as a species.

\section{Introducing the Contributions}

Questions about the relationship between early H. sapiens and sympatric or co-existing human species remain captivating. Since it became known that $H$. sapiens 'replaced' Neanderthals in Eurasia, heated debates ensued wherein most hypotheses focus on environmental pressures or inter-species competition (e.g. Conard 2011; Wolf et al. 2018; Timmermann 2020). Alternative models introduce scenarios of demographic weakness, migration, and drift to predict the demise of the Neanderthals (e.g. Kolodny and Feldman 2017; Degioanni et al. 2019). In sub-Saharan Africa on the other hand, researchers have been lulled into a model of gradual evolution based on seemingly continuous archaeological, fossil, and genetic records. The dating of the small-brained Homo naledi to between about 335,000 and 236,000 years ago (Berger et al. 2017), suggesting that they co-existed with early $H$. sapiens, came as a surprise to many. As a result, serious theoretical questions became apparent about the interpretation of the evolutionary and behavioural record of H. sapiens in southern Africa (e.g. Lombard et al. 2018; Hawks and Berger 2020). Dusseldorp and Lombard (2021) take on the challenge of investigating co-existence of Homo species. They do so by exploring the possible technological niche of $H$. naledi compared to that of $H$. sapiens, and by combining ecological principles such as competitive exclusion with the physical anthropological and archaeological records of the region. Their analysis reveals theoretical biases that impact on how we think about the evolution of techno-behaviours in extinct hominins. They conclude that the two species probably occupied different technological niches, and show that the framework they use may be applied to cases such as the co-existence of Neanderthals and H. sapiens in Eurasia or the co-existence of different tool makers during the Earlier Stone Age in East Africa.

Regardless of how it came to be, the broad consensus is that after about 300,000 years ago, and subsequent to the dispersal of $H$. sapiens out of Africa, there was a marked increase in the range and regularity within which key aspects of so-called modern human behaviour occur (e.g. French 2018). Yet, theoretical explanations that enabled the emergence of this new kind of human in biological, social, and technical terms remain lacking in scope (e.g. Moncel and Schreve 2016). In an effort to move discussion forward, Penny Spikins and her colleagues (Spikins et al. 2021) problematise the traditional view of so-called modern human behaviour (e.g. Henshilwood and Marean 2003; Mellars 2007), instead focussing on patterns of change that are evident in human social behaviours in Africa during the timeframe set for this special issue (also see Brooks et al. 2018; Petraglia et al. 2019; Rito et al. 2019). They use agent-based modelling to investigate different tolerance levels in between-group interactions. By assessing relative costs and benefits in relation to survival and resource 
exploitation in various environments, they infer a potential relationship between ecological variation and changes in between-group behavioural dynamics. From their results, they deduce that changes in intergroup tolerance hinged on variation in levels of environmental harshness. They therefore conclude that variation in intergroup tolerance emerges as an important explanation for both physiological and psychological tweaks that lead to social behaviour that is currently associated with the 'self-domestication' of $H$. sapiens. To them, their modelled scenario represents a more prudent explanation for the emergence of sapient behaviour than hypotheses that are centred around, for example, population size or cognition.

Whereas Bruner (2021) agrees that social changes (brought about by aspects of landuse and migration that required a fluid group structure) may have increased levels of cooperation through self-domestication in H. sapiens, he draws our attention back to the human brain and cognitive variation. His review of human palaeo-neurology captures the morphological similarities and differences in the brains of later Pleistocene populations. He shows how some of the variation that is traditionally associated with cognitive differences (e.g. the frontal lobe) may in fact result from constraints in cortical or cranial structure differences between the species, perhaps not affecting cognition much. Instead he highlights the bulging of the parietal region in both Neanderthals and $H$. sapiens and subsequent neurological changes in this region that are intimately linked with differences in functional cognition. For example, in terms of the post-300,000-year time slice, both $H$. sapiens and Neanderthals show changes in overall brain size as well as developing differences in specific cerebral regions (also see, e.g., Pereira-Pedro et al. 2017). As a result, functions associated with body cognition, visuospatial integration, tool use, language, and social structure may be involved, and may well have varied between the two species. Bruner further elaborates on the co-evolutionary processes of brain change that involve both genetic and environmental effects, bridging biological and cultural factors, which brings him to conclude that a brain-body prosthetic capacity may have been key to humans ultimately becoming obligatory tool users (e.g. Shea 2017).

Building on the notions of a brain-body prosthetic capacity, material signification, and creative material engagement inherent in humans today, namely Material Engagement Theory (Malafouris 2013), Malafouris (2021) explores the role of mark making in human becoming and the evolution of so-called human intelligence. Drawing on a theoretical perspective of continuous transformation wherein the human remains fluid and incomplete, always in a process of becoming (Gosden and Malafouris 2015; Ihde and Malafouris 2019), he presents an in-depth analysis of the well-known engraved ochre piece from Blombos Cave, South Africa (Henshilwood et al. 2002). This artefact, dated to about 72,000 years ago, remains one of the most iconic and innovative items that changed global perception of $H$. sapiens behaviour and thinking during the later stages of the African Middle Stone Age. Recent experimental work also showed how the Blombos engravings evolved adaptively as more suited for human perception and cognition through becoming increasingly salient, memorable, reproducible, and expressive of style and human intent (Tylén et al. 2020). In tandem with these findings, Malafouris' (2021) general hypothesis proposes that mark making represents "a salient point of intersection between matter and memory". Based on a profound engagement with the markings on the Blombos ochre piece, he concludes that a predominant focus on symbolic representation may blind us to other, more basic dimensions of the 
cognitive life and agency of such marks as material signs. Instead, he explains how 'becoming human' is inextricably linked to the mind-body experience of mark making - both internally and externally.

Turning inwards, the individual human brain mediates more than one state of consciousness. Monophasic cultures distinctive to modern technocracies typically fail to credence polyphasic experiences in alternative states, such as dreams, visions, ritually induced trances, and drug trips. Thus, neuro-archaeological accounts must involve an understanding of how brains mediate multiple states of consciousness (Sterling and Laughlin 2015). Drawing on creativity as pivotal to the human experience, Lyn Wadley zooms past the engraved ochre pieces from Blombos Cave only. Instead, she includes the rich spread of archaeological evidence for novel material culture items that embody human imagination during the Middle Stone Age and Middle Palaeolithic_-some of which are not species specific or exclusive to $H$. sapiens. Similar to the preceding papers in this issue, she suggests that it is not one but the likely intersection of multiple factors such as brain power, motor skill, and social need that stimulate human imagination and innovation. Working from Bruner's (2021) emphasis on the parietal cortex, Wadley (2021) also introduces neurological work that demonstrates relatively high levels of interconnectivity between several brain regions in 'highly creative people' (e.g. Beaty et al. 2018). She therefore argues that it is not only the degree to which the relative brain areas in humans developed and/or differ from each other, but that variation in the interactive fluency between the regions is equally relevant in terms of human creative expression. Although she underscores that the archaeological record of both symbolic and everyday objects shows that imagination was not the cognitive domain of $H$. sapiens only, she concludes that it is our species who clearly started to excel in terms of innovation and imaginative expression in material culture since about 100,000 years ago.

As humans, we do not only inherit the brains and neurological pathways moulded by our evolutionary path and the genes from our parents - we are also born into a lifespace shaped by culture. This cultural space is inextricably entangled in history, environment, technology, cosmology, and social organisation (e.g. Haidle et al. 2015). Merlin Donald (2012: 272) discusses co-evolutionary scenarios that would select for greater plasticity and improved learning capacity, making the brain subject to radical functional reorganisation by cultural forces. Hence, gene-culture co-evolution postulates an evolutionary feedback loop between ecology, culture, mind, body, and DNA that triggers trajectories in human evolution. In our contribution (Lombard and Högberg 2021), we develop this way of thinking by introducing a four-field coevolutionary model to discuss relationships between human cognitive evolution, biology, technology, society, and ecology. We reveal probable mechanisms for similarities in cognition between Neanderthals and H. sapiens in terms of symbolic behaviour and social learning before about 50,000 years ago. Yet we also highlight likely differences between the two populations in aspects of technical and social cognition. Our conclusion is that, based on a vast range of inter-disciplinary data and interpretations, dissimilarities in brain-selective gene variants and brain morphology strongly suggest differences in some evolutionary paths that would have affected cognition. We therefore suggest that a useful way forward might be to spend more effort on unravelling aspects of Neanderthal-specific cognition - instead of insisting on blanket similarity to that of $H$. sapiens. 


\section{In Summary}

Drawing on different theoretical pathways, the authors contributing to this volume all push the Middle Stone Age and/or Middle Palaeolithic interpretative envelope beyond what has become the traditional standards of 'symbolic behaviour' (e.g. Henshilwood and Marean 2003; Mellars 2007; Tattersall 2008; also see discussion in Burdukiewicz 2014), sometimes coupled with a relatively late and sudden 'development by mutation' model (e.g. Klein 2000). Both of these standards stem from a time when it was thought that the sapient mind originated at the break between the Middle and Upper Palaeolithic, around 50,000 to 40,000 years ago when so-called Cro-Magnons replaced the Neanderthals in Eurasia (e.g. White 1940; Jelinek 1982; White 1982; Chase and Dibble 1987; Marshack 1989; Lindly et al. 1990). They were also formulated before the dating revolution that enabled more accurate time estimates for the Middle Stone Age and Middle Palaeolithic records; before we knew about geneflow between the populations who lived during these phases; and before the archaeological and genetic records allowed us to rewrite human deep-time history. Subsequently, the notion of a symbolic revolution was shifted to Africa and/or to Neanderthal populations in Eurasia (e.g. Knight et al. 1995; d'Errico et al. 2003; Mellars 2005) - shoehorning old thought styles onto new finds and new data. The single-sudden mutation model has also now been reshuffled into that of an abrupt gene-constellation fixation to accommodate new genetic data (e.g. Klein 2019).

From the contributions in this special issue, wherein we encouraged participants to grow and deepen theoretical understanding of what it meant to 'be' or 'become' human during the Middle Stone Age and Middle Palaeolithic, it is easy to conclude that theoretical thinking on the topic has now moved well beyond these standards in either their old or revised forms. Spontaneously, two common threads crystallised throughout all the texts as part of what Fleck (1935) would have referred to as our thought collective:

1. The awareness that it is not a singular or particular aspect that suddenly made us human, instead many bits needed to come together through time to shape humanity in all its complexity.

2. Theoretical approaches that aim to explain deep-time human endeavour require integrated approaches from many different knowledge fields.

To use words from Daniel Lord Smail (2008: 3), we hope that the theoretical explorations presented in this special issue will help to expose the "old ideas that continue to structure our thinking without us being fully aware of their controlling presence", and offer new ways of thinking, exemplifying what asking new questions (or old questions in new ways) can contribute to how we understand human endeavour between 300,000 and 30,000 years ago.

Acknowledgements First, we thank all the authors who contributed their time and thoughts to this special issue, the idea of which originated from the session 'Theoretical approaches to techno-behaviours during the Middle Stone Age (Africa)/Middle Palaeolithic (Europe)' held during the SAfA-day at EAA2018 in Barcelona, Spain. Since then, some of the oral presentations went in different directions, and other contributions have been added, but we would like to thank all participants in the session for their thought-provoking papers and lively discussion. Also, thanks to the journal editor who attended the session in Barcelona, and believed in the merit of a resulting themed issue. All the papers benefitted from feedback provided by many reviewreaders across several disciplines, and we are deeply appreciative of their time and input. 
Funding Open Access funding provided by Linnaeus University.

Open Access This article is licensed under a Creative Commons Attribution 4.0 International License, which permits use, sharing, adaptation, distribution and reproduction in any medium or format, as long as you give appropriate credit to the original author(s) and the source, provide a link to the Creative Commons licence, and indicate if changes were made. The images or other third party material in this article are included in the article's Creative Commons licence, unless indicated otherwise in a credit line to the material. If material is not included in the article's Creative Commons licence and your intended use is not permitted by statutory regulation or exceeds the permitted use, you will need to obtain permission directly from the copyright holder. To view a copy of this licence, visit http://creativecommons.org/licenses/by/4.0/.

\section{References}

Baghramian, M. \& Carter, A. J. (2020). Relativism, The Stanford Encyclopedia of Philosophy (Fall 2020 Edition), Edward N. Zalta (ed.) https://plato.stanford.edu/archives/fall2020/entries/relativism/

Beaty, R. E., Kenett, Y. N., Christensen, A. P., Rosenberg, M. D., Benedeke, M., Chen, Q., et al. (2018). Robust prediction of individual creative ability from brain functional connectivity. Proceedings of the National Academy of Sciences, USA, 115(5), 1087-1092.

Beck, A. S., Dengsø, Jessen, M., Fahlander, F., Lucas, G. M., Fuglestvedt, I., \& Herva, V.-P. (2019). Will there be a next Nordic TAG? Reflections on theoretical archaeology in the Nordic countries today. Arkceologisk Forum, 41, 14-24.

Berger, L. R., Hawks, J., Dirks, P. H. G. M., Elliott, M., \& Roberts, E. M. (2017). Homo naledi and Pleistocene hominin evolution in subequatorial Africa. eLife, 6, e24234.

Binford, L. R. (1962). Archaeology as anthropology. American Antiquity, 28(2), 217-225.

Brooks, A. S., Yellen, J. E., Potts, R., Behrensmeyer, A. K., Deino, A. L., Leslie, D. E., Ambrose, S. H., Ferguson, J. R., d'Errico, F., Zipkin, A. M., Whittaker, S., Post, J., Veatch, E. G., Foecke, K., \& Clark, J. B. (2018). Long-distance stone transport and pigment use in the earliest Middle Stone Age. Science, 360(6384), 90-94.

Bruner, E. (2021). Evolving human brains: paleoneurology and the fate of Middle Pleistocene. Journal of Archaeological Method and Theory. https://doi.org/10.1007/s10816-020-09500-8.

Burdukiewicz, J. M. (2014). The origin of symbolic behavior of Middle Palaeolithic humans: recent controversies. Quaternary International, 326, 398-405.

Chase, P. G., \& Dibble, H. L. (1987). Middle Paleolithic symbolism: a review of current evidence and interpretations. Journal of Anthropological Archaeology, 6(3), 263-296.

Conard, N. J. (2011). The demise of the Neanderthal cultural niche and the beginning of the Upper Paleolithic in Southwestern Germany. In J. J. Conard \& J. Richter (Eds.), Neanderthal lifeways, subsistence and technology: one hundred years of Neanderthal study (pp. 223-240). Dordrecht: Springer.

d'Errico, F., Henshilwood, C., Lawson, G., Vanhaeren, M., Tillier, A. M., Soressi, M., \& Backwell, L. (2003). Archaeological evidence for the emergence of language, symbolism, and music: an alternative multidisciplinary perspective. Journal of World Prehistory, 17(1), 1-70.

Degioanni, A., Bonenfant, C., Cabut, S., \& Condemi, S. (2019). Living on the edge: was demographic weakness the cause of Neanderthal demise? PLoS One, 14(5), e0216742.

Donald, M. (1991). Origins of the modern mind. Three stages in the evolution of culture and cognition. Cambridge, MA: Harvard University Press.

Donald, M. (2001). A mind so rare: the evolution of human consciousness. New York: Norton and Company.

Donald, M. (2012). Evolutionary origins of autobiographical memory: a retrieval hypothesis. In D. Berntsen \& D. C. Rubin (Eds.), Understanding autobiographical memory: theories and approaches (pp. 269-289). Cambridge: Cambridge University Press.

Dusseldorp, G.L. \& Lombard, M. (2021). Constraining the likely technological niches of late Middle Pleistocene hominins with Homo naledi as case study. Journal of Archaeological Method and Theory. https://doi.org/10.1007/s10816-020-09501-7.

Fleck, L. (1935). Entstehung und Entwicklung einer wissenschaftlichen Tatsache. Einführung in die Lehre vom Denkstil und Denkkollektiv. Basel: Benno Schwabe und Co.. 
French, J. C. (2018). The Palaeolithic archaeological record and the materiality of imagination: a response to J. Wentzel van Huyssteen. In A. Fuentes \& C. Deane-Drummond (Eds.), Evolution of wisdom: major and minor keys (pp. 57-63). Press Books: Center for Theology, Science, and Human Flourishing.

Gosden, C., \& Malafouris, L. (2015). Process archaeology (P-Arch). World Archaeology, 47(5), 701-717.

Haidle, M. N., Bolus, M., Collard, M., Conard, N. J., Garofoli, D., Lombard, M., ... \& Whiten, A. (2015). The nature of culture: an eight-grade model for the evolution and expansion of cultural capacities in hominins and other animals. Journal of Anthropological Sciences. 93, 43-70.

Hawks, J., \& Berger, L. (2020). On Homo naledi and its significance in evolutionary anthropology. In C. Deane-Drummond \& A. Fuentes (Eds.), Theology and evolutionary anthropology: dialogues in wisdom, humility and grace (pp. 51-68). London: Routledge.

Henshilwood, C. S., \& Marean, C. W. (2003). The origin of modern human behavior. Current Anthropology, 44(5), 627-651.

Henshilwood, C. S., d'Errico, F., Yates, R., Jacobs, Z., Tribolo, C., Duller, G. A. T., Mercier, N., Sealy, J. C., Valladas, H., Watts, I., \& Wintle, A. G. (2002). Emergence of modern human behaviour: Middle Stone Age engravings from South Africa. Science, 295(5558), 1278-1280.

Herzfeld, M. (2001). Anthropology: theoretical practice in culture and society. Malden, MA: Blackwell.

Hodder, I. (1986). Reading the past. Current approaches to interpretation in archaeology. Cambridge: Cambridge University Press.

Hodder, I. (Ed.). (2005). Archaeological theory today. Cambridge: Polity Press.

Högberg, A. (2009). Lithics in the Scandinavian late bronze age. Sociotechnical change and persistence. Oxford: BAR International.

Holtorf, C. (2005). From Stonehenge to Las Vegas. Archaeology as popular culture. Walnut Creek: Altamira Press.

Holtorf, C., \& Högberg, A. (2015). Contemporary heritage and the future. In E. Waterton \& S. Watson (Eds.), The Palgrave handbook of contemporary heritage research (pp. 509-523). New York: Palgrave Macmillan.

Ihde, D., \& Malafouris, L. (2019). Homo faber revisited: postphenomenology and material engagement theory. Philosophy \& Technology, 32(2), 195-214.

Jelinek, A.J. (1982). The Middle Paleolithic in the southern Levant, with comments on the appearance of modern Homo sapiens. In A Ronen (Ed.). The transition from Lower to Middle Paleolithic and the origin of modern man (pp. 57-101). Oxford: B.a.R Int. series 151.

Johnson, M. (2020). Archaeological theory: an introduction (3rd ed.). Oxford: Wiley Blackwell.

Klein, R. G. (2000). Archaeology and the evolution of human behavior. Evolutionary Anthropology Issues News and Reviews, 9(1), 17-36.

Klein, R. G. (2019). Population structure and the evolution of Homo sapiens in Africa. Evolutionary Anthropology: Issues, News, and Reviews, https://oi.org/10.1002/evan.21788.

Knight, C., Power, C., \& Watts, I. (1995). The human symbolic revolution: a Darwinian account. Cambridge Archaeological Journal, 5(1), 75-114.

Kolodny, O., \& Feldman, M. W. (2017). A parsimonious neutral model suggests Neanderthal replacement was determined by migration and random species drift. Nature Communications, 8(1), 1-13.

Kuhn, S. L., \& Hovers, E. (2013). Alternative pathways to complexity: evolutionary trajectories in the Middle Paleolithic and Middle Stone Age. An introduction to supplement 8. Current Anthropology, 54(S8), S176-S182.

Lindly, J. M., Clark, G. A., Bar-Yosef, O., Lieberman, D., Shea, J., Dibble, H. L., ... \& Mellars, P. (1990). Symbolism and modern human origins [and comments and reply]. Current Anthropology, 31(3), 233261.

Lombard, M. \& Högberg, A. (2021). Four-field co-evolutionary model for human cognition: variation in the Middle Stone Age/Middle Palaeolithic. Journal of Archaeological Method and Theory. https://doi.org/10. 1007/s10816-020-09502-6.

Lombard, M., Jakobsson, M., \& Schlebusch, C. (2018). Ancient human DNA: How sequencing the genome of a boy from Ballito Bay changed human history. South African Journal of Science, 114(1-2), 1-3.

Lucas, G. (2005). The archaeology of time. Themes in archaeology. New York: Routledge.

Malafouris, L. (2013). How things shape the mind. A theory of material engagement. Cambridge Massachusetts: The MIT Press.

Malafouris, L. (2021). Mark making and human becoming. Journal of Archaeological Method and Theory. https://doi.org/10.1007/s10816-020-09504-4.

Marshack, A. (1989). Evolution of the human capacity: The symbolic evidence. American Journal of Physical Anthropology, 32(S10), 1-34. 
Mellars, P. (2005). The impossible coincidence. A single-species model for the origins of modern human behavior in Europe. Evolutionary Anthropology: Issues, News, and Reviews: Issues, News, and Reviews, 14(1), 12-27.

Mellars, P. (2007). Rethinking the human revolution: Eurasian and African perspectives. In P. Mellars, K. Boyle, O. Bar Yosef, \& C. Stringer (Eds.), Rethinking the human revolution (pp. 1-14). Cambridge: McDonald Institute Monographs.

Meskell, L., \& Preucel, R. W. (Eds.). (2004). A companion to social archaeology. Oxford: Blackwell Publishing.

Miller, D. (2005). Afterword. In L. Meskell (Ed.), Archaeologies of materiality (pp. 212-219). Oxford: Blackwell Publishing.

Moncel, M.-H., \& Schreve, D. (2016). The Acheulean in Europe: origins, evolution and dispersal. Quaternary International, 411, 1-8.

Olsen, B. (2010). In defence of things. Archaeology and the ontology of objects. New York: Altamira Press.

Pereira-Pedro, A. S., Masters, M., \& Bruner, E. (2017). Shape analysis of spatial relationships between orbitoocular and endocranial structures in modern humans and fossil hominids. Journal of Anatomy, 231(6), 947-960.

Petraglia, M. D., Breeze, P. S., \& Groucutt, H. S. (2019). Blue Arabia, Green Arabia: examining human colonisation and dispersal models. In N. M. A. Rasul \& I. C. F. Stewart (Eds.), Geological setting, palaeoenvironment and archaeology of the Red Sea (pp. 675-683). Dordrecht: Springer.

Renfrew, C. \& Zubrow, E. B. (Eds.) (1994). The ancient mind. Elements of cognitive archaeology. New directions in archaeology. Cambridge: Cambridge University Press.

Rito, T., Vieira, D., Silva, M., Conde-Sousa, E., Pereira, L., Mellars, P., Richards, M. B., \& Soares, P. (2019). A dispersal of Homo sapiens from southern to eastern Africa immediately preceded the out-of-Africa migration. Scientific Reports, 9(1), 4728.

Shanks, M. (1992). Experiencing the past. On the character of archaeology. London: Routledge.

Shea, J. J. (2017). Occasional, obligatory, and habitual stone tool use in hominin evolution. Evolutionary Anthropology, 26(5), 200-217.

Smail, L. D. (2008). On deep history and the brain. Berkeley: University of California Press.

Spikins, P., French, J.C., John-Wood, S., \& Dytham, C. (2021). Theoretical and methodological approaches to ecological changes, social behaviour and human intergroup tolerance 300,000 to 30,000 BP. Journal of Archaeological Method and Theory. https://doi.org/10.1007/s10816-020-09503-5.

Sterling, P., \& Laughlin, S. (2015). Principles of neural design. Cambridge, Massachusetts: The MIT Press.

Tattersall, I. (2008). An evolutionary framework for the acquisition of symbolic cognition by Homo sapiens. Comparative Cognition \& Behavior Reviews, 3, 99-114.

Timmermann, A. (2020). Quantifying the potential causes of Neanderthal extinction: abrupt climate change versus competition and interbreeding. Quaternary Science Reviews, 238, 106331.

Trigger, B. G. (2006). A history of archaeological thought. Cambridge: Cambridge University Press.

Tylén, K., Fusaroli, R., Rojo, S., Heimann, K., Fay, N., Johannsen, N. N., Riede, F., \& Lombard, M. (2020). The evolution of early symbolic behavior in Homo sapiens. Proceedings of the National Academy of Sciences, 117(9), 4578-4584.

Wadley, L. (2021). What stimulated rapid, cumulative innovation after 100,000 years ago? Journal of Archaeological Method and Theory. https://doi.org/10.1007/10.1007/s10816-020-09499-y.

Wenger, E. (1998). Communities of practice. Learning, meaning, and identity. Cambridge: Cambridge University Press.

White, L. A. (1940). The symbol: the origin and basis of human behavior. Philosophy of Science, 7(4), 451463.

White, R. (1982). Rethinking the Middlel Upper Paleolithic transition. Current Anthropology, 2, 95-115.

Wolf, D., Kolb, T., Alcaraz-Castaño, M., Heinrich, S., Baumgart, P., Calvo, R., ... \& Zech, R. (2018). Climate deteriorations and Neanderthal demise in interior Iberia. Scientific Reports, 8(1), 1-10.

Publisher's Note Springer Nature remains neutral with regard to jurisdictional claims in published maps and institutional affiliations. 